\title{
Ambient Air Quality in the Czech Republic
}

\author{
Iva Hůnová
}

check for updates

Citation: Hůnová, I. Ambient Air Quality in the Czech Republic. Atmosphere 2021, 12, 770. https:// doi.org/10.3390/atmos12060770

Received: 1 June 2021

Accepted: 9 June 2021

Published: 15 June 2021

Publisher's Note: MDPI stays neutral with regard to jurisdictional claims in published maps and institutional affiliations.

Copyright: (C) 2021 by the author. Licensee MDPI, Basel, Switzerland. This article is an open access article distributed under the terms and conditions of the Creative Commons Attribution (CC BY) license (https:// creativecommons.org/licenses/by/ $4.0 /)$.
Ambient Air Quality Department, Czech Hydrometeorological Institute, Na Šabatce 17, 14306 Prague 4, Czech Republic; iva.hunova@chmi.cz

\section{Introduction}

Ambient air quality in the present-day Czech Republic (CR), one of the two succession countries of Czechoslovakia post-1993, was perceived as a major problem with severe human health and environmental consequences, particularly between the 1970s and 1990s [1]. Since that time, the ambient air quality in the CR has improved substantially, due to newly introduced stringent legislation and technical countermeasures. Nevertheless, there are still activities which represent significant emission sources, such as local heating and increased vehicle travel through communities. After a substantial decrease in emissions in both the CR and its neighbouring countries, the levels of some ambient air pollutants from the 2000s are still not satisfactory [2]. In this respect, aerosol, ground-level ozone and benzo[a]pyrene remain major problems, as they do elsewhere in Europe [3].

This Special Issue of Atmosphere includes one review and 15 original research papers highlighting the progress achieved both in monitoring and modelling air pollution as an important supporting tool for improving of our living environment. Most of the contributions included are aerosol-focused. This editorial provides a short introduction to these interesting papers and presents them in a broader context.

\section{Summary of This Special Issue}

\subsection{Review on the Time Trends and Spatial Changes in Ambient Air Pollution}

In a detailed review, Ho̊nová [4] provides an overview of ambient air quality development in the present-day Czech Republic over the past seven decades, i.e., from the 1950s to present day. Major air pollution problems are highlighted, main hotspots and air pollutants are indicated, and air pollution impacts on both human health and the environment are discussed. This review provides a broader context for further contributions focussing more specifically on individual ambient air pollutants and issues.

\subsection{Aerosol Papers}

Most papers in this SI are devoted to one of the major ambient air pollutants, i.e., aerosol, by examining it from different perspectives. Volná and Hladký [5] studied the links between ambient $\mathrm{PM}_{10}$ concentrations and meteorological conditions over the Czech-Polish border area, a hot spot region not only in the CR but for the whole of Europe. The analysis of ultrafine particles, $\mathrm{PM}_{2.5}$, from the same region is provided by Seibert et al. [6], who used the Positive Matrix Factorization approach to identify sources of local air pollution. Their results indicated that the major factors to be blamed for pollution are emissions from residential heating and the burning of solid fuels, followed by the regional primary and secondary aerosol sources, whereas long-range transport and heavy industry appeared to be of only minor importance. Pavlíková et al. [7] measured 34 elements in $\mathrm{PM}_{10}$ sampled in the centre of Ostravsko-karvinská agglomeration at the top of a former mining tower at a height of $90 \mathrm{~m}$ above ground to investigate regional air pollution. The elemental composition was found to be seasonal-dependent, and it varied due to sampling conditions. Three large industrial sources were identified as major contributors to regional ambient air pollution, though these were not detected by conventional ground-level air monitoring. 
Furthermore, $\mathrm{PM}_{10}$ trans-boundary transport from Polish emission sources was indicated to play a major role in winter, contributing substantially to air pollution in the studied region.

Using numerical modelling, Pospisil et al. [8] studied dispersion characteristics of $\mathrm{PM}_{10}$ in the vicinity of roads passing different types of urban areas. The authors pointed out that major parameters influencing the final shape of the $\mathrm{PM}_{10}$ mass concentration field are wind direction and velocity, and the built-up area's geometry substantially modifies air flow velocity at the ground-level layers of the atmosphere. That the geometry of built-up areas is important for ambient $\mathrm{PM}_{10}$ levels in cities is also supported by Neubauer et al. [9], who studied hourly parallel records from two stations in Brno, one located in a park, the other one in a built-up area. The authors concluded that, apart from meteorology, this factor should definitely be accounted for in assessment of $\mathrm{PM}_{10}$ pollution in densely populated urban areas with high levels of traffic.

Ďoubalová et al. [10] used a high-resolution weather and air-quality forecast system to simulate a typical winter air pollution episode in January-February 2017 in the capital, Prague. Their results confirmed previous findings about urbanisation's effect on ambient air quality in winter, indicating the general behaviour of air pollution in cities in the winter period, regardless of the region or specific air pollution situation. Unique measurements of exhaust $\mathrm{PM}_{10}$ emissions from two diesel-electric locomotives and one diesel-hydraulic railcar, carried by Vojtisek-Lom et al. [11] during scheduled passenger service, revealed that, despite the fact that these engines were approaching the end of their lives, their emissions were substantially lower compared to cars. These data are very valuable, as information on train emissions is practically non-existent.

Mikuška et al. [12] sampled submicron $\mathrm{PM}_{1}$ aerosol particles in two Czech urbanized areas: a large city, Brno, and a small town, Šlapanice. They did so through campaigns during heating and non-heating seasons in 2009-2010. Whereas the mean $\mathrm{PM}_{1}$ concentrations were nearly identical in summer, the mean $\mathrm{PM}_{1}$ concentrations in winter were 1.6 times higher in the small town. Based on analysis of 14 elements and 12 water-soluble ions, the principal aerosol emission sources were identified. Brzezina et al. [13] studied nanoparticle number concentrations of 61 size fractions (ranging between ca. $200 \mathrm{~nm}$ and $15 \mu \mathrm{m}$ in aerodynamic diameter) in the air at a traffic site in Ústí nad Labem to compare the behaviour of various size fractions within a day, a week, and a year. They attributed the differences in variability of individual size fractions to pollution sources, physical properties of particles, and to meteorological and dispersion conditions.

\subsection{Benzo[a]pyrene in Ambient Air}

A thorough analysis on ambient benzo[a]pyrene $(\mathrm{BaP})$ concentrations is provided by Schreiberová et al. [14]. They pointed out that, during the period of 2012-2018, a full $35-58 \%$ of the urban population in the $\mathrm{CR}$ were exposed to $\mathrm{BaP}$ concentrations above the target value. According to the data from 48 Czech measuring sites, the mean ambient BaP levels ranged from $0.4 \mathrm{ng} \cdot \mathrm{m}^{-3}$ at a rural regional station to $7.7 \mathrm{ng} \cdot \mathrm{m}^{-3}$ at an industrial station. Furthermore, short-term campaign measurements in small settlements revealed high values of daily $\mathrm{BaP}$ concentrations in winter seasons related to local heating.

\subsection{Nitrogen Oxides in Ambient Air}

Though exhibiting spatially limited ambient air quality levels, nitrogen oxides $\left(\mathrm{NO}_{\mathrm{x}}\right)$ emitted by traffic represent a major problem at busy roads in many urbanized areas. In their work, Vojtisek-Lom et al. [15] examined the effects of two problematic recent trends related to increasing use of diesel passenger cars: (i) increasing ambient $\mathrm{NO}_{2} / \mathrm{NO}_{\mathrm{x}}$ ratio resulting from conversion of $\mathrm{NO}$ into $\mathrm{NO}_{2}$ in catalysts, and (ii) disparity between vehicle emission limits and real emission impacts on ambient air quality due to everyday driving in Prague. They concluded that decreases in $\mathrm{NO}_{x}$ emission limits for vehicles, introduced in recent decades, have apparently failed to sufficiently reduce ambient $\mathrm{NO}_{2}$ levels in Prague. 


\subsection{Low-Cost Air Quality Sensors}

With an ever-increasing need to control ambient air pollution in cities and industrial areas, we have recently witnessed a boom in demand for low-cost air quality sensors. Bauerová et al. [16] presented the results of almost a one-year field experiment comparing the results of different low-cost sensors and co-located measurements by reference methods used in the Czech nation-wide ambient air quality monitoring network. The authors pointed out the importance of long-term comparison studies through which scientific recommendations are transferred to the general public, providing valuable assistance in decision-making processes when buying suitable types of sensors and eliminating of possible flaws in their application; these revelations also help producers in further enhancing their own products.

\subsection{Regional and Urban Background Ambient Air Pollution}

The ambient air concentrations from regional stations are important as reference sites, providing ambient air quality levels for comparison to impact areas, such as cities and industrial regions. For the $\mathrm{CR}$, the National Atmospheric Observatory Košetice operated by the Czech Hydrometeorological Institute, established in 1988, which participates in numerous international programs, projects, and activities, serves as an important monitoring site by providing data describing the air pollution at a regional scale. Váňa et al. [17] summarized the long-term time trends in principle ambient air pollutants at the Košetice Observatory in the context of air pollutant emission changes.

Huzlík et al. [18] examined the ambient air quality in park areas in Brno, the second largest city of the CR. In spite of a general belief that green urban areas provide the best air quality within the city, the measurements supporting this claim are mostly lacking. Based on four 14-day campaigns measuring $\mathrm{NO}, \mathrm{NO}_{2}, \mathrm{PM}_{10}$, and $\mathrm{O}_{3}$ levels, Huzlík et al. [18] concluded that the air quality in the parks approached that of the urban background sites, except for Koliště park, where similar ambient air pollution levels as at the traffic site were measured.

\subsection{Emissions}

The only emission-oriented paper of this SI focuses on fluorinated greenhouse gases (F-gases) that have been developed to replace stratospheric ozone-depleting substances, and which are used in refrigeration and air-conditioning systems. Although not harmful to the ozone layer, F-gases contribute substantially to the greenhouse effect and global climate change; hence, they are deserving of world-wide attention. Müllerová et al. [19] provided information on changes in the composition of F-gases used in the CR.

\section{Concluding Remark}

To conclude, the papers presented in this SI provide a valuable update both on time trends and spatial changes in ambient air quality, and highlight the recent activities in both monitoring and modelling of principle ambient air pollutants in the $C R$.

Funding: This research received no external funding.

Institutional Review Board Statement: Not applicable.

Informed Consent Statement: Not applicable.

Conflicts of Interest: The author declares no conflict of interest.

\section{References}

1. Moldan, B.; Schnoor, J.L. Czechoslovakia-Examining a Critically Ill Environment. Environ. Sci. Technol. 1992, 26, 14-21. [CrossRef]

2. CHMI. Air Pollution in the Czech Republic in 2018; Graphical Yearbook (Czech/English); Czech Hydrometeorological Institute: Prague, Czech Republic, 2019. 
3. EEA. Air Quality in Europe-2019 Report; EEA Report No. 10/2019; EEA: Copenhagen, Denmark, 2019. Available online: https:// www.eea.europa.eu/publications / air-quality-in-europe-2019/air-quality-in-europe-2019/viewfile\#pdfjs.action=download (accessed on 30 February 2020).

4. Hůnová, I. Ambient Air Quality in the Czech Republic: Past and Present. Atmosphere 2020, 11, 214. [CrossRef]

5. Volná, V.; Hladký, D. Detailed Assessment of the Effects of Meteorological Conditions on PM $_{10}$ Concentrations in the Northeastern Part of the Czech Republic. Atmosphere 2020, 11, 497. [CrossRef]

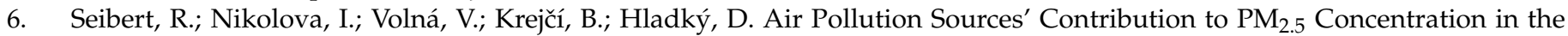
Northeastern Part of the Czech Republic. Atmosphere 2020, 11, 522. [CrossRef]

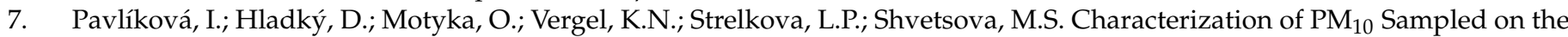
Top of a Former Mining Tower by the High-Volume Wind Direction-Dependent Sampler Using INNA. Atmosphere 2021, 12, 29. [CrossRef]

8. Pospisil, J.; Huzlik, J.; Licbinsky, R.; Spilacek, M. Dispersion Characteristics of $\mathrm{PM}_{10}$ Particles Identified by Numerical Simulation in the Vicinity of Roads Passing through Various Types of Urban Areas. Atmosphere 2020, 11, 454. [CrossRef]

9. Neubauer, J.; Michálek, J.; Šilinger, K.; Firbas, P. Impacts of Built-Up Area Geometry on PM 10 Levels: A Case Study in Brno, Czech Republic. Atmosphere 2020, 11, 1042. [CrossRef]

10. Ďoubalová, J.; Huszár, P.; Eben, K.; Benešová, N.; Belda, M.; Vlček, O.; Karlický, J.; Geletič, J.; Halenka, T. High Resolution Air Quality Forecasting over Prague within the URBI PRAGENSI Project: Model Performance during the Winter Period and the Effect of Urban Parameterization on PM. Atmosphere 2020, 11, 625. [CrossRef]

11. Vojtisek-Lom, M.; Jirků, J.; Pechout, M. Real-World Exhaust Emissions of Diesel Locomotives and Motorized Railcars during Scheduled Passenger Train Runs on Czech Railroads. Atmosphere 2020, 11, 582. [CrossRef]

12. Mikuška, P.; Vojtěšek, M.; Křůmal, K.; Mikušková-Čampulová, M.; Michálek, J.; Večeřa, Z. Characterization and Source Identification of Elements and Water-Soluble Ions in Submicrometre Aerosols in Brno and Šlapanice (Czech Republic). Atmosphere 2020, 11, 688. [CrossRef]

13. Brzezina, J.; Köbölová, K.; Adamec, V. Nanoparticle Number Concentration in the Air in Relation to the Time of the Year and Time of the Day. Atmosphere 2020, 11, 523. [CrossRef]

14. Schreiberová, M.; Vlasáková, L.; Vlček, O.; Šmejdířová, J.; Horálek, J.; Bieser, J. Benzo[a]pyrene in the Ambient Air in the Czech Republic: Emission Sources, Current and Long-Term Monitoring Analysis and Human Exposure. Atmosphere 2020, 11, 955. [CrossRef]

15. Vojtisek-Lom, M.; Suta, M.; Sikorova, J.; Sram, R.J. High $\mathrm{NO}_{2}$ Concentrations Measured by Passive Samplers in Czech Cities: Unresolved Aftermath of Dieselgate? Atmosphere 2021, 12, 649. [CrossRef]

16. Bauerová, P.; Šindelářová, A.; Rychlík, Š.; Novák, Z.; Keder, J. Low-Cost Air Quality Sensors: One-Year Field Comparative Measurement of Different Gas Sensor and Particle Counters with Reference Monitors at Tušimice Observatory. Atmosphere 2020, 11, 492. [CrossRef]

17. Váňa, M.; Holubová-Šmejkalová, A.; Svobodová, J.; Machálek, P. Long-Term Trends of Air Pollution at National Atmospheric Observatory Košetice (ACTRIS, EMEP, GAW). Atmosphere 2020, 11, 537. [CrossRef]

18. Huzlík, J.; Hegrová, J.; Effenberger, K.; Ličbinský, R.; Brtnický, M. Air Quality in Brno City Parks. Atmosphere 2020, 11, 510. [CrossRef]

19. Müllerová, M.; Krtková, E.; Rošková, Z. F-Gases: Trends, Applications and Newly Applied Gases in the Czech Republic. Atmosphere 2020, 11, 455. [CrossRef] 